\title{
Prioritizing Short-Termism in Behavioural Strategy: Lessons from Enron - 20 Years On
}

\author{
Gianpaolo Abatecola ${ }^{1}$ \\ ${ }^{1}$ University of Rome Tor Vergata, Italy \\ Correspondence: Gianpaolo Abatecola, University of Rome Tor Vergata, Italy. E-mail: \\ abatecola@economia.uniroma2.it \\ Received: December 23, 2018 \\ Accepted: February 20, 2019 \\ Online Published: March 8, 2019 \\ doi:10.5539/ijbm.v14n4p60 \\ URL: https://doi.org/10.5539/ijbm.v14n4p60
}

\begin{abstract}
What are the risks of prioritizing short-term goals in corporate strategy against more long-term oriented (and hopefully sustainable) corporate performance? Through a qualitative case study narrative recalling some aspects of the sadly famous, but still insightful, bankruptcy of the Enron Corporation in the US (2001), this article aims at contributing to shed light on this lively research question within the international research on and practice of behavioural strategy. Given that, also currently, the seasons of corporate scandals do not seem to have ended, the main motivation behind this work is that the lessons which we could have learned after almost 20 years since the Enron seminal disaster occurred, can still probably have a value. In parallel, the main conceptual contribution offered by our case perspective is that, while the massive past and recent Enron's coverage has mostly devoted attention to the aspects of fraud and its associated business ethics, our analysis is, instead, focused on the corporate strategic orientation mainly deriving from the macho culture of the top executives. Of course, we are aware that concentrating on the latter cannot avoid acknowledging also the importance of the former. Furthermore, the case can also offer a methodological contribution; in fact, while much of the research in corporate governance has been implemented through quantitative techniques, scholars have also recently claimed that additional qualitative research is complementarily needed to reach a more exhaustive big picture on how executives behave.
\end{abstract}

Keywords: Behavioral Strategy, Chief Executives, Bankruptcy, Case Study, Business Ethics, Fraud, Corporate Governance, Higher Education

\section{Introduction}

What are the risks of prioritizing short-term (almost purely financial) goals in corporate strategy against more long-term oriented (and hopefully sustainable) corporate performance? Through a qualitative case study analysis recalling some aspects of the sadly famous, but still insightful, bankruptcy of the Enron Corporation in the US (2001), this article aims at contributing to shed light on this lively research question within the international research on and practice of behavioural strategy (e.g. Kahneman, Lovallo, \& Sibony, 2011; Levinthal, 2011; Powell, Lovallo, \& Fox, 2011).

Behavioural strategy issues are fast growing in academic and public policy debates. While the initial lines of inquiry on the topic arose following Hambrick and Mason's (1984) seminal Upper Echelons Theory, in the new millennium, the relevance of behavioural strategy has been also highlighted by a number of financial frauds occurring, all of a sudden, worldwide (e.g. Enron, WorldCom, Tyco, Adelphia, Global Crossing, Cirio and Parmalat). Unfortunately, notwithstanding the serious attempts made to reform the corporate governance systems in many countries, huge and controversial corporate scandals, such as Petrobras in 2014, and Volkswagen's Dieselgate in 2015, have continued (and seemingly still continue) to receive primary attention worldwide. This is why, at least we believe, the lessons which we could have learned after almost 20 years since the Enron seminal disaster occurred (e.g. Healy \& Palepu, 2003; Watkins, 2003; Abatecola, 2004), and which some have probably forgotten, still probably merit additional attention; and, of course, contributing to filling this (tremendously) important knowledge gap for both scholars and practitioners also constitutes the main motivation behind this work.

On this premise, two main problems from the financial scandals mentioned above have become dramatically significant: the huge managerial expropriation of corporate resources and, simultaneously, the great financial 
damage caused to investors. This is substantially why, today, from a generally accepted, perspective (e.g. Powell, 2017; Sibony, Lovallo, \& Powell, 2017), behavioural strategy "merges cognitive and social psychology with strategic management theory and practice. It thus aims to bring realistic assumptions about human cognition, emotions, and social behavior to the strategic management of organizations and, thereby, to enrich strategy theory, empirical research, and real-world practice" (Powell et al., 2011, p. 1371).

This introduced, much of the existing (and also recent) research on behavioural strategy (e.g. Liu, Vlaev, Fang, Denrell, \& Chater, 2017; Mazutis \& Eckardt, 2017) has been grounded in the seminally bounded rationality concept (Simon, 1947); and, from this perspective, behavioural strategy has, more than once, been faced with the opportunities and threats offered by the classical theory of shareholder value maximization (Fruhan, 1979; Rappaport, 1986) with regard to the firm's main purpose. On this side, we also know that one of the most relevant problems highlighted by this theory is that of the (almost pure) short-termism in planning (and subsequently executing) corporate goals; a problem which, as some inappropriate practice of business still demonstrates, seemingly continues to be present in the life of corporate executives and top managers around the world. This is why the explanatory power deriving from the Enron tragedy still appears to be impactful. Thus, in this article, we narrate the most significant happenings in the firm's life cycle through commenting on the most controversial behavioural strategies developed by the firm's upper echelons. Stemming from the discussion of Enron's strategic direction and business model, we then derive some potential avenues for research and practice.

Much has been written and documented about the Enron case over the years. It has been covered by a number of judicial inquiries, committee hearings, scientific articles, business reports, TV shows, books, and even thought-provoking movies. In the light of this, we believe that the main conceptual contribution offered by our case perspective is that, while the past and recent Enron's coverage has mostly devoted attention to the aspects of fraud and its associated business ethics, our analysis is, instead, focused on the corporate strategic orientation mainly deriving from the macho culture of the top executives. Of course, we are aware that, for an appropriate interpretation of the case, concentrating on the latter cannot avoid acknowledging also the importance of the former. Furthermore, the case can also offer a methodological contribution; in fact, while much of the research in corporate governance has been implemented through quantitative techniques, scholars have also recently claimed that additional qualitative research is complementarily needed to reach a more exhaustive big picture on how executives behave (e.g. McNulty, Zattoni, \& Douglas, 2013).

In sum, regarding the theoretical and methodological positioning of our analysis, the management literature has often evidenced the importance of economic and financial sub-goals for behavioural strategy, in particular agreeing that they provide essential support in the definition of long-term strategic intents (e.g. Golinelli, 2010; Koller, Goedhart, \& Wessels, 2010; Radic, 2015). However, the literature has also been extremely cautious in supporting those management models in which the weight of these goals is so heavy that it entirely subordinates the overall corporate strategic orientation (e.g. Cafferata, 2016; Grant, 2016; Barile, Pellicano, \& Polese, 2018). The literature, in other words, continues to claim that short-termism must not become the principal (and almost unique) engine of the firm's management (e.g. Zingales, 2012; Westphal \& Zajac, 2013; Paniccia \& Leoni, 2017), if the practice of business wants to avoid tremendously negative consequences. In this regard, we believe that Enron (and others discovered later) continues to appear as more than a possibly dramatic, but still illustrative, example to teach in business schools.

\section{Methodology and Context: From Hero to Zero}

From a methodological point of view, in our analysis we adopted the most recent techniques of qualitative research and case study methodology (e.g. Symon \& Cassell, 2012; Lee \& Saunders, 2017). We adopted a quasi-historical case design, because pure history "is the preferred method when there is virtually no such control or access" (Yin, 2013: 12). Thus, to write the Enron narrative we used multiple sources, with most of the data collected from public domains. In particular, we analyzed hundreds of documents related to Enron's economic/financial performance and story, such as: $i$ ) balance sheets and financial statements; ii) analysts' coverage; iii) stock prices; iv) publicly released interviews; v) scientific journal articles (e.g. Bratton, 2002; Schwarcz, 2002); v) official reports from many Committee Hearings held in the United States of America (e.g. Oxley, 2002; Powers, Troubh, \& Winokur, 2002); vi) famous documentary movies and books (e.g. McLean \& Elkind, 2004); vii) articles from business newspapers and magazines, such as Financial Times (e.g. Kay, 2002), New York Times (e.g. Krugman, 2001), Forbes (e.g. Levine, 2006; Niles, 2009), Wall Street Journal (e.g. Lublin, 2002), Fortune (e.g. McLean, 2001), Business Week (e.g. Zellner, Forest Anderson, \& Cohn, 2002), and The Economist (e.g. 2002).

On this premise, at the beginning of the new century, Enron, the famous US energy giant, was highly appreciated 
by financial markets in general, and at the New York Stock Exchange in particular. However, in March 2001, a Fortune journalist, Bethany McLean, wrote a financial article which soon became popular. Entitled "Is Enron overpriced" (McLean, 2001), and attempting to address the simple question "How does Enron exactly make profits?", this article had the courage to raise the first worries about Enron's business model, with a particular focus on the lack of disclosure seemingly prevailing in its financial reports yearly released. Then, in a series of following meetings, Arthur Andersen, the famous auditing company, also expressed to Enron its concerns about various accounting procedures used by its client over time.

The suspicions above publicly increased even more in August, causing the quick decrease of Enron's stock price from the peak of $90 \$$ share reached in July to $50 \$ /$ share. In the same month, Enron's CEO Jeffrey Skilling, whose favourite book was The Selfish Gene (Dawkins, 1976), suddenly resigned from his position for "personal reasons"; Enron's Chairman Kenneth Lay, instead, sold about 100,000 Enron shares of which, in the meanwhile, he had become owner through the exercise of his stock options in the corporation. On the one hand, he also continued to publicly encourage investors to buy Enron's stocks; on the other, he imposed to the firm's pension fund the ban on selling Enron's stocks.

As a consequence of all the events above, the US Securities and Exchange Commission (SEC) opened a judicial inquiry in October, asking Enron to explain the accounting operations regarding the structuring and functioning of many of its intra-group subsidiaries over the years (in that month, the stock price also collapsed to about $10 \$$ share). Thus, in November, not only Enron announced significant losses in the third financial quarter; it also admitted the necessity to restate its financial reports regarding the period 1997-2000, because of the need to consolidate some subsidiaries on the basis of the SEC findings. That retroactive consolidation caused a massive reduction of the net income, increase of liabilities, and decrease of net assets respectively.

At the end of November, with its real economic and financial situation definitely emerged, Enron's stock was downgraded to "junk" value, this bringing the contractual need to immediately refund a huge amount of corporate bonds. From that, the final attempt to save Enron through the merger with Dynegy, one of its most relevant competitors in the energy industry, also failed. Formalizing the state of insolvency thus became unavoidable and, in the early December, 2001, Enron entered Chapter 11 of the American Bankruptcy Code. The stock price, in the meanwhile, collapsed to $0.2 \$$ share: from being a hero to being a zero in only five months.

\section{Case Narrative}

In terms of policy making (e.g. Niskanen, 2007), Enron has raised partially opposite scientific positions: on the one hand, it has been used to highlight the inefficiencies of the American capitalism of that time; on the other, more daringly (we would maintain), it has been used to argue that only American capitalism could have brought to light a strategic posture so unscrupulous as to exceed the weak threshold between aggressive accounting and accounting fraud. We comment on this below.

\subsection{Gas Bank: When the Executives' Mind-Set Becomes an Inspiring Business Model}

Initially characterizing itself as a hard asset, traditional public utility, with its core business in the distribution of natural gas, Enron was founded in 1985 through the merger of Houston Natural Gas (Texas) and InterNorth (Nebraska); a merger from which Enron inherited the longest set of gas pipelines existing, at that time, in the US. Almost since the beginning, however, the firm started an ambitious but unscrupulous expansion, which, in its strategic and organizational features, followed the macho culture of its founders (Oreg \& Berson, 2019). On the one hand, in particular, Enron's founders and top executives, i.e., as mentioned, the Chairman Kenneth Lay, and the CEO Jeffrey Skilling, were in total support of the deregulation process occurring in the US energy industry in the 1980s. These executives, on the other hand, also firmly believed that, to govern the business competitiveness featured by a new high velocity environmental regime, the light asset company business model had to be adopted as soon as possible. "I am Enron": this is the (narcissistic) expression which Skilling, over time, loved to use in almost all his public interviews.

The business model planned above started its development in 1989, the year in which Enron began its intermediation activity regarding the distribution of gas. In that period, Enron was facing difficulties in optimizing the distribution capacity of its pipelines, because of the problems in meeting the demand and offer of gas. Buyers, on the one hand, aimed at protecting themselves through setting long-term supply contracts; sellers, on the other, aimed at speculating on the frequent gas price fluctuations through short-term contracts.

Enron thus decided to create its Gas Bank, a huge data-driven structure setting long-term contracts with both the gas suppliers and clients. Enron paid the former in advance, providing them with cash immediately available for reinvestment; it then sold the acquired gas to the latter, while, at the same time, hedging on price risks. From the 
beginning, the markets demonstrated appreciation for Gas Bank, whose performance was brilliant: on the one hand, through contemporaneously protecting both the producers and customers from price fluctuations, it significantly helped Enron improve the use of its gas pipelines, thus its productive capacity; on the other hand, through the mark-to-market measurement of contracts, Enron could register revenues in advance, i.e. before the temporal conclusion of the contracts.

From a behavioural strategy perspective, Gas Bank represented the first evolutionary variation (e.g. Johansson \& Kask 2013; Gordini, 2014; McCarthy, Collard, \& Johnson, 2017; Belussi, 2018; Grandinetti, 2018) of Enron's business model. Indeed, on the basis of the first competitive success, the corporation started a strategic path which, very quickly, radically transformed its core business from the traditional management of gas pipelines to the trading of increasingly sophisticated derivative contracts - natural gas first, and a number of increasingly differentiated commodities subsequently. In particular, this change brought the progressive dismissal of hard assets and ended with the almost total abandonment of every industrial activity.

\subsection{The Most Innovative Company in Corporate America}

In the 1990s, Enron progressively diversified the Gas Bank successful business model to every other deregulated industry in US, such as electricity, water, steel, and weather forecasting. Diversification was supported by internationalization, with Enron also sponsoring deregulation abroad and entering in South America (e.g. Brazil), Europe (e.g. Great Britain), and Asia (e.g. India). Diversification and internationalization also represented a success in terms of performance, with the stock price grown, toward the end of that decade, of about four times the initial quotation.

From a behavioural strategy point of view, however, we could consider the actions above as an incremental variation in Enron's business model. 1999, instead, seemingly constitutes the year in which the corporation executed its second (and last) radical change, through which it definitely became a global financial conglomerate mainly focused on the trading of ever riskier and speculative derivatives contracts in Over-the-Counter (OTC) markets. That year, in fact, witnessed the birth of Enrononline, a virtual, private Stock Exchange that, in some way, we could also consider as the main ancestor of the current online trading platforms. Again strongly data-driven, Enrononline let the demand and offer of a number of traded goods fit, making profits on the transactions occurring. Because of its breakthrough functioning, this platform quickly became the most crowded private e-commerce website in the world.

The impact of all the activities narrated in this section, and especially of Enrononline, on Enron's performance appears to be fabulous, with its share price reaching the highest value of $90 \$ /$ share in July, 2000. Enrononline also seems to conclude the initial strategic plan of transforming the firm into a light asset company, with the weight of light assets increasing from about 30\% in 1999 to above 60\% in 2000. In that year, Enron's reputation was so fantastic that the Fortune business magazine elected it as "The Most Innovative Company in America" for the fifth continuous year and ranked it at number 7 in its specific Fortune 500 ranking. Since the beginning, Lay and Skilling's visionary dream was that of developing Enron as "virtual corporation, i.e. a centre for market making and hedging by high tech experts, rather than an asset-heavy energy producer" (Bratton, 2002: 1285); well, that dream had seemingly become true.

\subsection{Creative Finance and Star Wars}

What we have reported in the preceding pages could be summarized as follows: to support its ambitious growth strategy, almost from the beginning Enron became totally focused on reaching short-term (financial) goals. Every activity became specifically oriented towards maximizing the value of income, stock prices, and dividends. Implementing these goals very soon implied a radical change to Enron's core business, which shifted from industrial to financial. In fact, Lay and Skilling considered the trading of commodities, rather than their production, as a necessary condition to adapt to the rapid development of the new economy. Abstracting from Skilling's strictly Darwinian view of competition, "those that adapt best displace the rest" (Henderson, 1989: 140). In this regard, the development of the creative finance system explained in this section can help understand how.

An interesting starting point here can be 1989, i.e. the year in which Enron created Gas Bank. Despite, as written, its apparent success, Gas Bank was also a source of problems to Enron, especially as far as financing its rapid expansion is concerned: Lay and Skilling, in fact, clearly needed the immediate availability of financial resources for the payment in advance of the furniture contracts. External funding, on the one hand, did not appear as an appropriate choice, because the supposed growth of the leverage rate would have significantly decreased Enron rating and, thus, reputation; adding new equity, on the other, did not also appear appropriate, because would have decreased the individual value of the already existing shares, thus eliciting the negative 
reaction of shareholders.

To obtain the necessary funding, without simultaneously increasing debts, Enron thus used the Special Purpose Entities (SPEs), which, as known, can be conceived as specific financial instruments, often formalized into autonomous group subsidiaries, temporarily used by firms to perform specific transactions with a predetermined goal. The implementation of SPEs goes back to the 1970s, with particular regard to leasing operations, and with subsequent use in other financial contexts such as credit securitization. Over time, the great opportunity which SPEs have offered is that, under the satisfaction of some specific conditions, the American accounting rules allowed avoiding their inclusion in the balance sheet of their parental corporations. From that, a massive use by American multinationals has also derived.

On this premise, what, among others, matters in the Enron case is that, among the accounting conditions to be contemporaneously satisfied for being legally allowed to avoid the SPEs' consolidation, a SPE's administration had to be given to a trustee, which needed to be a party independent of the transferor (i.e. Enron, the parental corporation). In contrast, if, in any given moment, this condition was missing, the transferor had to consolidate the SPE as a traditional subsidiary, thus adding the SPE's assets and liabilities to its balance sheet (Schwarcz, 2002). Moreover, the intragroup operations had also to be eliminated: for example, if, previously, the selling of assets from the transferor to the SPE had already been registered as a revenue, a retroactive restatement of the transferor's financial statement was needed. On this basis, an illustrative example of how the SPEs' implementation was developed at Enron can be offered by the anecdotal evidence below; it comes from the seminal and famous JEDI-Chewco operation, whose name not casually (especially given the creativity of Enron's top managers) recalls the two well-known characters of the Star Wars milestone movie.

At the beginning of the 1990s, Enron set up a joint venture with the California Public Employees Retirement System (CalPERS), the investment fund managed by the social security system of California's public employees. In particular, the Joint Energy Development Investment Limited Partnership (JEDI LP) was founded, with its core business in energy investments. Neither of the business partners had exclusive control of JEDI (both owned $50 \%$ equity): thus, Enron, using the accounting rules on consolidation, excluded JEDI from its consolidated balance sheet and financial statement.

JEDI soon revealed to be extremely profitable; in the second half of the decade, as a consequence, Enron proposed to CalPERS the creation of another limited liability partnership. However, CalPERS stated that it would accept only if Enron bought its entire equity stock in JEDI. Enron knew that if it became the exclusive owner of JEDI, it could no longer be able to avoid consolidating it; and also knew that not only was JEDI highly profitable, but also extremely full of debt.

Enron solved the problem above creating a SPE, Chewco Investments LP, which was intended to buy CalPERS' equity in JEDI and, contemporaneously complying with the accounting rules, could have avoided being consolidated in Enron itself. To this purpose, the 3\% of the overall equity invested by Chewco was provided by two corporations: Big River and Little River Funding. The remaining $97 \%$ of the investment was provided as loan capital, i.e. financed for about $65 \%$ by Barclays Bank, and for the remaining $35 \%$ by JEDI itself to Chewco through a complex accounting mechanism.

Chewco's structure apparently seemed compliant with the recalled rules set by the American accounting standards, which, under certain conditions, permitted avoiding SPEs' consolidation; in fact, its administration was performed by both Big and Little River, whose stock was equal to $3 \%$ of the equity. Later, however, what emerged is that, at the time of Chewco's creation, the controlling shareholder of Big and Little River was an Enron manager, Michael Kopper, who also substantially managed Chewco. Thus, on the basis of the extant accounting rules, it is evident that Chewco, and its subsidiary JEDI (full of debt) should have been consolidated in Enron from the beginning (Powers et al., 2002).

In sum, Enron soon developed a contrived system (Katz \& Kahn, 1966) of financial transactions, which have been later labelled as "creative", based on developing a vast network of SPEs (about 1,000 at the beginning of the new century); given the high economic returns initially provided, this system was, from its start, also able to attract equity from some among the most relevant institutional investors at an international level. Benefitting from important financial know-how, more complex SPEs in turn came to light, their core business being associated with leasing transactions, plant selling, hedging and equity investments.

This huge and articulated structure not only progressively provided Enron with important funding outside the balance sheet liabilities, but also became one of the most significant financial instruments to support the restyling of Enron's accounting books, for example through dismissing the least profitable assets, or covering the losses from the mistakes in growth strategy (e.g. the wrong investments in the Wessex Water and Dabhol power stations 
respectively). In fact, the administration of many SPEs was directly undertaken by Andrew Fastow, Enron's CFO. This, of course, replicated the scheme, illegal with respect to the possibility of avoiding the SPEs' consolidation, already experimented with Chewco Investments, as we have explained above.

\section{Discussion}

In the preceding case narrative we have reported the most relevant aspects regarding the famous Enron collapse and, specifically, we have explained the most problematic business practices supporting short-termism in its behavioural strategic orientation. As also advocated in the latest 2019 World Economic Forum in Davos, if we start from the assumption that the most important goals for firms (and institutions) should be survival and long-term sustainability, we can argue that corporate strategic orientation is effective if it allows firms to be competitive over the short-term, while simultaneously allowing them to implement those resources and capabilities needed to be competitive over the long-term (e.g. Dobson, Breslin, Suckley, Barton, \& Rodriguez, 2013; Grant, 2016; Aquilani, Silvestri, Ruggieri, \& Gatti, 2017).

On this premise, Enron's radical change in its core business was not apparently supported by the prudential and appropriate evaluation of the nature of the critical success factors for its new business model (e.g. Mari \& Poggesi, 2013; Di Carlo, Fortuna, \& Testarmata, 2016; Carrubbo, Iandolo, Pitardi, \& Calabrese, 2017; Foss \& Saebi, 2018). In fact, Enron, almost from the beginning, transformed itself from a traditional distributor of natural gas to a financial intermediary, even though financial intermediaries, as well as all the other economic agents, need market trust as an essential condition of survival (Carretta, Farina, Schwizer, Fiordelisi, \& Stentella Lopes, 2015; Gibilaro \& Mattarocci, 2018). This trust must be acquired, implemented and properly consolidated over time (e.g. Delbufalo, 2012), thus determining a co-evolutionary relationship with the firm (Breslin, 2016; Cafferata, 2016; Paniccia \& Baiocco, 2018; Uli, 2018).

In Enron's case, the dynamic above has been superficially interpreted by Lay and Skilling, who have presumably believed that market trust could simply be acquired through positive economic results; this also apparently explains the obsessive search for accountable income through the abnormal use of financial leverage and creative finance, associated, as we narrated, with repeatedly fraudulent accounting transactions. Enron's upper echelons have also believed that market trust could be consolidated (until becoming almost unlimited) simply through stabilizing the economic results. This belief has thus brought the structuring of ever riskier SPEs, whose net value, in a particularly aggressive form of leverage, was strictly fed by the value of Enron's shares. Of course, as happened starting from the second half of 2001, when the share value collapsed, the SPEs' value followed, with the run on the bank in late November as the ultimate, ineluctable consequence.

In sum, Enron's business model, through all the steps explained in the case narrative and further highlighted in this section, can demonstrate how the behavioural strategies of the firms' top decision makers can be careless, and how markets ultimately pay considerable attention not only to how many the performances are, but also to how they are produced (e.g. Abratt \& Mingione, 2017). Thus, from this perspective, Enron seems to evidence the potential risks deriving from pure short-termism in behavioural strategy - risks which, however, we cannot seemingly associate with the intrinsic validity of the shareholder value maximization as a specific approach to strategic decision making; approach which, incidentally, has been also able to provide both scholars and practitioners with many successful business examples at international level (e.g. Mocciaro Li Destri, Picone, \& Minà, 2012).

Shareholder value, however, can generate business practices, which, sometimes, misinterpret its conceptual goals and theoretical pillars; thus, the propensity to orient the firm's management almost exclusively towards profit maximization over the short-term is, still, not rare (Mintzberg, 2013). If supported, when not directly driven by legislative insufficiencies and particularly unscrupulous managerial cultures, this propensity can produce a number of "Enron-like" effects. In this regard, some years ago Sumantra Goshal (2005) entitled one of his most famous and challenging articles "Bad Management Theories are Destroying Good Management Practices". We would argue here that the opposite can also be true.

\subsection{Implications}

From all we have discussed, we believe that Enron can still provide management scholars and practitioners with a number of insights useful to both research and policy making, with five, in our opinion, meriting particular attention.

The first insight is conceptual and specifically in regard to the future opportunity to study the intrinsic nature of the Enron collapse: in particular, scholars might attempt to position the Enron crisis typology among the extant conceptual classifications of corporate crisis, thus deepening the eventual specificities of this typology from a 
crisis management perspective (e.g. Abatecola, Farina, \& Gordini, 2014; Ciampi, 2015; Adriaanse \& van der Rest, 2017; Konig, Graf-Vlachy, Bundy, \& Little, 2018). From this point of view, could we perhaps define Enron as a moral hazard crisis? In particular, with this (maybe thought-provoking) term we could refer to all those corporate situations, mainly regarding listed firms, in which the investor relations reveal to be the most relevant critical success factor for long-term competitiveness. Thus, in those situations, the co-evolutionary circle between firm's reputation, high profits, and increase in the share value, can suddenly change from virtuous to vicious. As happened at Enron, in fact, little is needed to make this positive spiral turn from source of development to source of decline and, ultimately, failure.

Still conceptual, the second take-away is in regard to the study of what determinants frequently push firms to almost exclusively orient their management towards the reaching of financial short-term goals; thus determining, in some cases, a real shareholder value syndrome (Mintzberg, 2013). On this side, we should question whether this propensity is the consequence of a globally changed managerial culture, or if it is the consequence of the constant increase of competitive pressures, which ultimately brings an almost exclusive focus on short-term results. This propensity, of which Enron seems to be a terrible but very illustrative example, should be tackled as soon as possible through efficiently and effectively redefining the "rules of the game" at an international level, for example with a more impactful focus on business ethics (e.g. Pellegrini \& Ciappei, 2015), disclosure systems (e.g. Monteduro, 2017), remuneration schemes for executives and (top) managers (e.g. Gabrielsson, 2017), and, also, cross-country financial literacy (e.g. Nicolini, Cude, \& Chatterjee, 2013). To this purpose, we know that several corporate governance reforms have been undertaken over the past (e.g. Sarbanes-Oxley Act in the US) and recent (e.g. Dodd-Frank Act) years. However, some firms, banks, and even country-systems seemingly continue to fail for controversial reasons. Thus, the sensation here is that much has still to be done, not only from a research point of view, but also from a practical policy making perspective (e.g. Aguilera \& Jackson, 2010; Minichilli, Zattoni, Nielsen, \& Huse, 2012; Gnan, Hinna, Monteduro, \& Scarozza, 2013).

All this explained, the third implication, is, instead, methodological. For many years Enron's most famous promotional slogan was, with no doubt, "Ask Why". Specifically, with this thought-provoking catch phrase, Lay and Skilling intended to persuade the continuously increasing investors, shareholders, and employees, that a new "work culture" was possible; that the opportunities offered by the "blue ocean" (Kim \& Mauborgne, 2015) new economy were tremendously higher than those normally offered by the traditional "red ocean" economy; in sum, that all the dreams could become true simply through incomparable ambition and the hardest work. In this regard, this macho culture also introduced the well-known rank and yank (aggressive) performance appraisal system to assess which employees had to be promoted and which had to be downgraded, or even fired.

On the point above, in our analysis we have hopefully contributed to explain why Enron occurred: as written, the feeling is that, in this case, the corporate strategic orientation has been significantly determined not only, in general, by the self-reinforcing processes (e.g. Abatecola, 2014), cognitive biases (e.g. Caputo, 2016) and emotions (e.g. Cristofaro, 2018) of the top decision makers, but also, much more specifically, by their managerial greed, hubris, narcissism, and ego (Grijalva \& Harms, 2014; Picone, Dagnino, \& Minà, 2014). In contrast, the exhaustive understanding of the Enron collapse would risk being inappropriate if we do not give the right weight to that culture of extremism which has accompanied the corporation from its inception to its death.

This stated, we have contributed to explain the why question through analysing what took place and how. In this regard, with this also constituting a possible limitation to our analysis, we are aware that addressing the why question could be further improved by focusing on other important elements, such as Enron Board of Directors composition, or (top) management remuneration and reward structure. In particular, we believe that focusing on these elements would be also relevant to apprehend the reason why, for many years, the top executives were allowed to register huge profits, in the ways that we have explained, without any significant inquiry from, at least, the most relevant stakeholders. In other words, it seems challenging that the stakeholders overlooked a situation in which the performance of about 1,000 SPEs were not, at least, mentioned in the group annual reports; especially because, as evidenced, those SPEs contributed to the majority of the group profits.

About the ownership structure mentioned above, for example, a specific reflection could be merited by the relationship between a public company and its economic subject; the latter is, almost always, its top management team, which assumes full control of the corporate strategic decision-making process. On this side, Enron seems to offer an additional example of how, in this kind of organizational form, the overall corporate strategic orientation cannot, sometimes, result in being aligned to the shareholders' interests, thus raising the overarching agency problems (e.g. Westphal \& Zajac, 2013).

Also related to the third implication, and still methodological, the fourth possible suggestion for further 
investigations then is regarding the possibility to generalize the Enron case findings through a future multiple case study comprising similar happenings in the same period; on this side, however, we are conscious that, because of law and privacy-evident reasons, obtaining relevant primary data about financial frauds has always been a difficult task for researchers. This clarified, and as anticipated, we know that, although probably the most impressive ever, Enron does not represent the only scandal emerging at the beginning of the new century. Simply to recall the most impactful, some months before Enron, for example, the first controversial news regarding the reliability of the financials of Lernout \& Hauspie Speech Products (L\&H) emerged in Belgium. In particular, L\&H declared bankruptcy after being discovered responsible for fraudulent behaviours involving banks and other stakeholders in Europe, the US, and Asia.

Instead, after the explosion of Enron, the year 2002 definitely witnessed the season of the financial scandals in the US, with various Too Big to Fail giants of corporate America as the main protagonists. A leader in the telecommunication industry worldwide, Worldcom represented one of the largest bankruptcies ever in the US; at the same time, at least the cases of Global Crossing (optical fibres), Qwest and Dynegy (energy), Adelphia Communication (cable television), and Xerox (printing) cannot avoid significant mentioning. Further, in this context Italy was also present with the sadly known Cirio and Parmalat.

Finally, from all the conceptual and methodological implications above, the fifth (and last) implication can take the form of a point and counterpoint argument. In particular, on the one hand, one could argue that all the mentioned financial frauds caused dramatic damages to many stakeholders at different levels; but, on the other hand, one could also argue that the majority of corporations in the business arena were reliable. Similarly to Enron, some of these true corporations have also demonstrated searching for relevant short-term (financial) performance, but without raising any controversy about their business ethics. In fact, through appropriate and correct disclosure, these corporations showed (and show) fair and transparent assessment of their economic, financial, and organizational positioning. Thus, overall, it seems that the wisdom of corporate top decision makers can still be an important buffer against the assumption that a strong financial approach to behavioural strategy is, per se, not sustainable.

\subsection{Conclusion}

Also on the basis of the implications prospected above, we could finally argue that, however, one side of the Enron story still seems to raise convergent interpretations; in all its tragedy, this scandal has had the positive effect of revealing the urgency of legislative reforms and, more generally, the need to rethink the role of all the agents operating, at different levels, in the socio-economic system (e.g. Rapoport, Van Niel, \& Dharan; 2009; Primbs \& Wang, 2016).

In higher education programmes, positive examples of superstar CEOs, such as Elon Musk, Giorgio Armani, Jeff Bezos, Richard Branson, or Jack Ma, are typically those we use for inspiring our students when starting our management classes at undergraduate, graduate, and, especially, executive level. On this side, we firmly believe that the story of Kenneth Lay, Jeff Skilling, and others who followed, should also be seriously highlighted (and scientifically explained) when educating our $X, Y$, and $Z$ generations of students, i.e. the managers of our present and (hopefully) future.

\section{References}

Abatecola, G. (2004). Il rapporto tra economia e finanza nel governo dell'impresa. Il caso Enron. Economia e diritto del terziario, 16(3), 648-672.

Abatecola, G. (2014). Untangling self-reinforcing processes in managerial decision making. Co-evolving heuristics? Management Decision, 52(5), 934-949. https://doi.org/10.1108/MD-10-2013-0543

Abatecola, G., Farina, V., \& Gordini, N. (2014). Board effectiveness in corporate crises. Lessons from the evolving empirical research. Corporate Governance: The International Journal of Business in Society, 14(4), 531-542. https://doi.org/10.1108/CG-03-2013-0030.

Abratt, R., \& Mingione, M. (2017). Corporate identity, strategy and change. Journal of Brand Management, 24(2), 129-139. https://doi.org/10.1057/s41262-017-0026-8.

Adriaanse, J., \& van der Rest, J. P. (Eds.) (2017). Turnaround management and bankruptcy. New York and London: Routledge.

Aguilera, R. V., \& Jackson, G. (2010). Comparative and international corporate governance. The Academy of Management Annals, 4(1), 485-556. https://doi.org/10.1080/19416520.2010.495525.

Aquilani, B., Silvestri, C., Ruggieri, A., \& Gatti, C. (2017). A systematic literature review on total quality 
management critical success factors and the identification of new avenues of research. The TQM Journal, 29(1), 184-213. https://doi.org/10.1108/TQM-01-2016-0003

Barile, S., Pellicano, M., \& Polese, F. (Eds.) (2018). Social dynamics in a systems perspective. The Netherlands: Springer.

Belussi, F. (2018). New perspectives on the evolution of clusters. European Planning Studies, 26(9), 1796-1814. https://doi.org/10.1080/09654313.2018.1492059

Bratton, W. W. (2002). Enron and the dark side of shareholder value. Tulane Law Review, 76, 1265-1361.

Breslin, D. (2016). What evolves in organizational co-evolution? Journal of Management and Governance, 20(1), 45-67. https://doi.org/10.1007/s10997-014-9302-0

Cafferata, R. (2016). Darwinist connections between the systemness of social organizations and their evolution. Journal of Management and Governance, 20(1), 19-44. https://doi.org/10.1007/s10997-014-9303-z.

Caputo, A. (2016). Overcoming judgmental biases in negotiations: A scenario-based survey analysis on third party direct intervention. Journal of Business Research, 69(10), 4304-4312. https://doi.org/10.1016/j.jbusres.2016.04.004

Carretta, A., Farina, V., Fiordelisi, F., Schwizer, P., \& Stentella Lopes, F. S. (2015). Don't stand so close to me: The role of supervisory style in banking stability. Journal of Banking and Finance, 52, 180-188. https://doi.org/10.1016/j.jbankfin.2014.09.015

Carrubbo, L., Iandolo, F., Pitardi, V., \& Calabrese, M. (2017). The viable decision maker for CAS survival: How to change and adapt through fitting process. Journal of Service Theory and Practice, 27(5), 6-23. https://doi.org/10.1108/JSTP-09-2015-0202

Ciampi, F. (2015), Corporate governance characteristics and default prediction modelling for small enterprises. An empirical analysis of Italian firms. Journal of Business Research, 68(5), 1012-1025, https://doi.org/10.1016/j.jbusres.2014.10.003

Cristofaro, M. (2018). The role of affect in management decisions: A systematic review. European Management Journal. https://doi.org/10.1016/j.emj.2018.12.002

Dawkins, R. (1976). The selfish gene. New York, NY: Oxford University Press.

Delbufalo, E. (2012). Outcomes of inter-organizational trust in supply chain relationships: A systematic literature review and a meta-analysis of the empirical evidence. Supply Chain Management: An International Journal, 17(4), 377-402. https://doi.org/10.1108/13598541211246549

Di Carlo, E., Fortuna, F., \& Testarmata, S. (2016). Boundaries of the business model within business groups. Journal of Management and Governance, 20(2), 321-362. https://doi.org/10.1007/s10997-015-9338-9

Dobson, S., Breslin, D., Suckley, L., Barton, R., \& Rodriguez, S. (2013). Small firm survival and innovation. An evolutionary approach. International Journal of Entrepreneurship and Innovation, 14(2), 69-80. https://doi.org/10.5367/ijei.2013.0112

Foss, N. J., \& Saebi, T. (2018). Business models and business model innovation: Between wicked and paradigmatic problems. Long Range Planning, 51(1), 9-21. https://doi.org/10.1016/j.lrp.2017.07.006

Fruhan, W. E. (1979). Financial strategy: Studies in the creation, transfer and destruction of shareholder value. Homewood, IL: Irwin.

Gabrielsson, J. (2017). Handbook of research on corporate governance and entrepreneurship. Chelthenam, UK, and Northampton, US: Edward Elgar.

Ghoshal, S. (2005). Bad management theories are destroying good management practices. Academy of Management Learning \& Education, 4(1), 75-91. http://dx.doi.org/10.5465/AMLE.2005.16132558

Gibilaro, L., \& Mattarocci, G. (2018). Multiple banking relationships and exposure at default: Evidence from the Italian market. Journal of Financial Regulation and Compliance, 26(1), 2-19. https://doi.org/10.1108/JFRC-04-2016-0031

Gnan, L., Hinna, A., Monteduro, F., \& Scarozza, D. (2013). Corporate governance and management practices: Stakeholder involvement, quality and sustainability tools adoption. Evidences in local public utilities. Journal of Management and Governance, 17(4), 907-937. https://doi.org/10.1007/s10997-011-9201-6

Golinelli, G. M. (2010). Viable Systems Approach (VSA). Governing business dynamics. Padua: CEDAM. 
Gordini, N. (2014). A genetic algorithm approach for SME bankruptcy prediction: Empirical evidence from Italy. Expert Systems with Applications, 41(14), 6433-6445. https://doi.org/10.1016/j.eswa.2014.04.026

Grandinetti, R. (2018). Is organizational evolution Darwinian and/or Lamarckian? International Journal of Organizational Analysis, 26(5), 858-874. https://doi.org/10.1108/IJOA-03-2018-1367

Grant, R. M. (2016). Contemporary strategy analysis: Text and cases (9th ed.). New York, NY: Wiley.

Grijalva, E., \& Harms, P. D. (2014). Narcissism: An integrative synthesis and dominance complementarity model. Academy of Management Perspectives, 28(2), 108-127. https://doi.org/10.5465/amp.2012.0048

Hambrick, D. C., \& Mason, P. A. (1984). Upper echelons: The organization as a reflection of its top managers. Academy of Management Review, 9(2), 193-206. https://doi.org/10.5465/amr.1984.4277628

Healy, P. M., \& Palepu, K. G. (2003). The fall of Enron. Journal of Economic Perspectives, 17(2), 3-26. https://doi.org/10.1257/089533003765888403

Henderson, B. D. (1989). The origin of strategy. Harvard Business Review, 67(6), 139-143.

Johansson, T., \& Kask, J. (2013). On the promise and premises of a Darwinian theory in research on business $\begin{array}{llll}\text { relationships. Industrial Marketing } & \text { Management, }\end{array}$ https://doi.org/10.1016/j.indmarman.2013.02.006

Kahneman, D., Lovallo, D., \& Sibony, O. (2011). The big idea. Before you make that big decision. Harvard Business Review, 89(6), 50-60.

Katz, D., \&Kahn, R. L. (1966). The social psychology of organizations. New York: Wiley.

Kay, J. (2002). Enron. Financial Times.

Kim, W. C., \& Mauborgne, R. (2015). Blue ocean strategy (Expanded edition): How to create uncontested market space and make the competition irrelevant. Cambridge, MA: Harvard Business School Press.

Koller, T., Goedhart, M., \& Wessels, D. (2010). Valuation. Measuring and managing the value of companies (5th ed.). New York, NY: Wiley.

Konig, A. S., Graf-Vlachy, L., Bundy, J. N., \& Little, L. (2018). A blessing and a curse: How CEOs' empathy affects their management of organizational crises. Academy of Management Review, https://doi.org/10.5465/amr.2017.0387

Krugman, P. (2001). Laissez not fair. New York Times.

Lee, B., \& Saunders, M. (2017). Conducting case study research for business and management students. London, UK: Sage.

Levine, G. (2006). Fastow tells of loss-hiding Enron "Raptors". Forbes.

Levinhtal, D. A. (2011). A behavioural approach to strategy - What's the alternative? Strategic Management Journal, 32(13), 1517-1523. https://doi.org/10.1002/smj.963

Liu, C., Vlaev, I., Fang, C., Denrell, J., \& Chater, N. 2017. Strategizing with biases: Making better decisions using the mindspace approach. California Management Review, 59(3), 135-161. https://doi.org/10.1177/0008125617707973

Lublin, J. S. (2002, February 1). Enron Audit Panel Is Scrutinized For Its Cozy Ties With the Firm. Wall Street Journal.

Mari, M., \& Poggesi, S. (2013). Servicescape cues and customer behaviour: A systematic literature review and research agenda. The Service Industries Journal, 33(2), 171-199. https://doi.org/10.1080/02642069.2011.613934.

Mazutis, D., \& Eckardt, A. (2017). Sleepwalking into catastrophe: Cognitive biases and corporate climate change inertia. California Management Review, 59(3), 74-108. https://doi.org/10.1177/0008125617707974

McCarthy, I., Collard, M., \& Johnson, M. (2017). Adaptive organizational resilience: An evolutionary perspective. Current Opinion in Environmental Sustainability, 28, 33-40. https://doi.org/10.1016/j.cosust.2017.07.005

McLean, B. (2001). Is Enron overpriced? Fortune.

McLean, B., \& Elkind, P. (2004). The smartest guys in the room. The amazing rise and scandalous fall of Enron. New York, US: Penguin Books. 
McNulty, T. Zattoni, A., \& Douglas, T. (2013). Developing corporate governance research through qualitative methods: A review of previous studies. Corporate Governance: An International Review, 21(2), 183-198. https://doi.org/10.1111/corg.12006

Minichilli, A., Zattoni, A., Nielsen, S., \& Huse, M. (2012). Board task performance: An exploration of microand macro-level determinants of board effectiveness. Journal of Organizational Behaviour, 33(2), 193-215. https://doi.org/10.1002/job.743

Mintzberg, H. (2013). Simply managing. What managers do - And can do better. San Francisco, US: Berrett-Koehler Publishers.

Mocciaro Li Destri, A., Picone, P. M., \& Minà, A. (2012). Bringing strategy back into financial systems of performance measurement: Integrating EVA and PBC. Business System Review, 1(1), 85-102.

Monteduro, F. (2017). The adoption of outcome-related performance indicators in external reporting: An empirical study. International Journal of Public Administration, 40(10), 860-874. https://doi.org/10.1080/01900692.2017.1280824

Nicolini, G., Cude, B. J., \& Chatterjee, S. (2013). Financial literacy: A comparative study across four countries. International Journal of Consumer Studies, 37(6), 1-17, https://doi.org/10.1111/ijcs.12050

Niles, S. (2009). In pictures: 10 all-time great CEO outbursts: Jeffrey Skilling. Forbes.

Niskanen, W. A. (2007). After Enron. Lessons for public policy. Lanham, US: Rowman \& Littlefield Publishers.

Oreg, S., \& Berson, Y. (2019). Leaders' impact on organizational change: Bridging theoretical and methodological chasms. Academy of Management Annals, 13(1). https://doi.org/10.5465/annals.2016.0138

Oxley, M. G. (2002). The Enron collapse: Impact on investors and financial markets. Committee Hearing, Washington, DC.

Paniccia, P. M. A., \& Baiocco, S. (2018). Co-evolution of the University technology transfer: Towards a sustainability-oriented industry: Evidence from Italy. Sustainability, 10(12), 4675. https://doi.org/10.3390/su10124675

Paniccia, P. M. A., \& Leoni, L. (2017). Co-evolution in tourism: The case of Albergo Diffuso. Current Issues in Tourism. https://doi.org/10.1080/13683500.2017.1367763

Partnoy, F. (2002). Testimony before the United States Senate Committee on Governmental Affairs. Committee Hearing, Washington, DC.

Pellegrini, M. M., \& Ciappei, C. (2015). Ethical judgment and radical business changes: The role of entrepreneurial perspicacity. Journal of Business Ethics, 128(4), 769-788. https://doi.org/10.1007/s10551-013-1988-4.

Picone, P. M., Dagnino, G. B., \& Minà, A. (2014). The origin of failure: A multidimensional appraisal of the hubris hypothesis and proposed research agenda. Academy of Management Perspectives, 28(4), 447-468. https://doi.org/10.5465/amp.2012.0177

Powell, T. C. (2017). Strategy as diligence: Putting behavioural strategy into practice. California Management Review, 59(3), 162-190. https://doi.org/10.1177/0008125617707975

Powell, T. C., Lovallo, D., \& Fox, C. R. (2011). Behavioral strategy. Strategic Management Journal, 32(13), 369-1386. https://doi.org/10.1002/smj.968

Powers, W. C., Troubh, R. S., \& Winokur, H. S. (2002). Report of investigation (Powers' report). Committee Hearing, Special Investigative Committee of the Board of Directors of Enron Corp.

Primbs, M., \& Wang, C. (2016). Notable governance failures: Enron, Siemens and beyond. Comparative Corporate Governance and Financial Regulation, 3.

Radic, N. (2015). Shareholder value creation in Japanese banking. Journal of Banking and Finance, 52, 199-207, https://doi.org/10.1016/j.jbankfin.2014.09.014

Rapoport, N. B., Van Niel, J. D., \& Dharan, B. G. (2009). Enron and the other corporate fiascos: The Corporate Scandal Reader. US: Foundation Press.

Rappaport, A. (1986). Creating shareholder value. The new standard for business performance. New York, NY: The Free Press.

Schwarcz, S. L. (2002). Enron, and the use and abuse of Special Purpose Entities in corporate structures. 
University of Cincinnati Law Review, 70(4), 1309-1318.

Sibony, O., Lovallo, D., \& Powell, T. C. (2017). Behavioural strategy and the strategic decision architecture of the firm. California Management Review, 59(3), 5-21. https://doi.org/10.1177/0008125617712256

Simon, H. A. (1947). Administrative Behaviour. New York: The Free Press.

Symon, G., \& Cassell, C. (Eds.) (2012). The practice of qualitative organizational research: Core methods and current challenges. London, UK: Sage.

The Economist (2002). Bush and Enron's collapse.

Uli, V. (2018). A multilevel co-evolutionary perspective on organizational adaptation. Evidence from the service industry. Business Process Management Journal, 24(3), 652-670. https://doi.org/10.1108/BPMJ-01-2016-0008

Watkins, S. (2003). Ethical conflicts at Enron: Moral responsibility in corporate capitalism. California Management Review, 45(4), 6-19. https://doi.org/10.2307/41166185

Westphal, J., \& Zajac, E. (2013). A behavioral theory of corporate governance: Explicating the mechanisms of socially situated and socially constituted agency. Academy of Management Annals, 7(1), 607-661. https://doi.org/10.1080/19416520.2013.783669

Yin, R. K. (2013). Case study research: Design and methods (5th ed). Thousand Oaks: Sage.

Zellner, W., Forest Anderson, S., \& Cohn, L. (2002). A hero - and a smoking gun letter. Business Week.

Zingales, L. (2012). A capitalism for the people. Recapturing the lost genius of American prosperity. New York, NY: Basic Books.

\section{Copyrights}

Copyright for this article is retained by the author(s), with first publication rights granted to the journal.

This is an open-access article distributed under the terms and conditions of the Creative Commons Attribution license (http://creativecommons.org/licenses/by/4.0/). 